\title{
Puusepp's sign: a Babinski's sign equivalent
}

\section{Chandramohan Sharma, Mihir Acharya, Bansi Lal Kumawat, Pritesh Agarwal}

Department of Neurology, Sawai Mansingh Medical College and Hospital, Jaipur, Rajasthan, India

\section{Correspondence to} Professor Chandramohan Sharma, cmsharma65@hotmail.com Accepted 12 March 2014
CrossMark

\section{To cite: Sharma C,} Acharya M, Kumawat BL, et al. BMJ Case Rep Published online: [please include Day Month Year] doi:10.1136/bcr-2014203834

\section{DESCRIPTION}

Babinski's sign (extensor plantar response),${ }^{1}$ which is characterised by dorsiflexion of the great toe and variable fanning of the lateral four toes, is the prototype sign of upper motor neuron-type lesion. It is

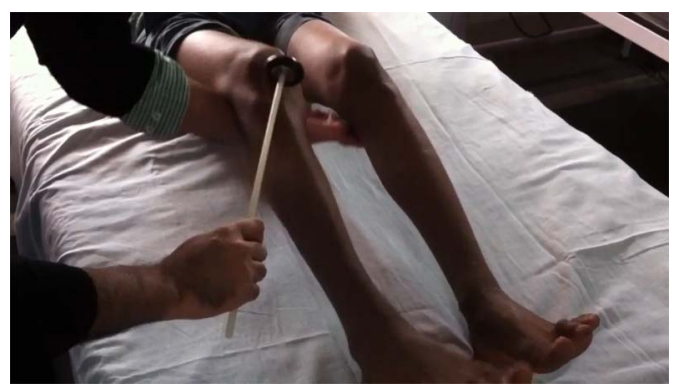

Video 1 Puusepp's sign-abduction of the little toe on plantar stimulation; without any movement of the great toe and brisk deep tendon reflexes at the knee.

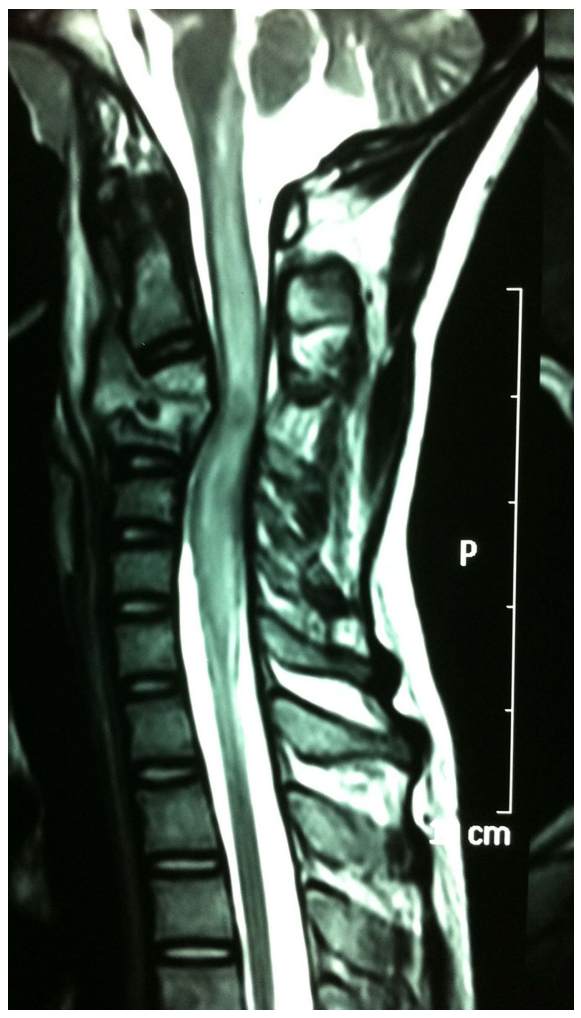

Figure 1 MRI T2-weighted sagittal image showing compressive cervical myelopathy at the C3-C4 level with destruction of the vertebral body-Pott's spine. elicited by stimulation of the lateral aspect of the sole with a blunt object. A large number of variations and modifications have been described in the literature for eliciting the extensor plantar response; the most useful ones being the Chaddock sign and the Oppenheim sign. All these methods concentrate on the initial movement of the great toe.

Puusepp's sign ${ }^{2}$ was originally described by the Estonian neurologist Ludvig Puusepp. It is the tonic, slow abduction of the little toe on plantar stimulation and may be present when the great toe extension is absent (video 1). We demonstrate Puusepp's sign in a patient with compressive cervical myelopathy due to tuberculosis-Pott's spine and paravertebral abscess (figure 1), in whom the Babinski's sign was not elicitable even in the presence of other upper motor neuron signs like spasticity and brisk deep tendon reflexes. The importance of Puusepp's sign is that, although rarely recognised in clinical practice, it may be the only elicitable sign in certain patients with upper motor neuron type pathology and thus helps in establishing the clinical diagnosis. Thus, observing the little toe in addition to the great toe while stimulating the lateral aspect of the sole for Babinski's sign provides important clinical information.

\section{Learning points}

- Puusepp's sign is the tonic, slow abduction movement of the little toe on stimulation of the lateral aspect of the sole with a blunt object.

- Clinical significance of Puusepp's sign arises in cases with upper motor neuron-type lesions and absent Babinski's sign; in which case it points to corticospinal tract pathology.

Contributors All authors contributed to the planning, conduct and reporting of the work described in the article, and justifiably credited with authorship, according to the authorship criteria. All authors read and approved the final version of the manuscript. $\mathrm{CS}$ is the guarantor.

\section{Competing interests None.}

Patient consent Obtained.

Provenance and peer review Not commissioned; externally pee reviewed.

\section{REFERENCES}

1 Goetz CG. History of the extensor plantar response: Babinski and Chaddock signs. Semin Neurol 2002;22:391-8.

2 Tacik P, Krasnianski M, Zierz S. Puusepp's sign-clinical significance of a forgotten pyramidal sign. Clin Neurol Neurosurg 2009;111:919-21. 


\section{Images in...}

Copyright 2014 BMJ Publishing Group. All rights reserved. For permission to reuse any of this content visit http://group.bmj.com/group/rights-licensing/permissions.

BMJ Case Report Fellows may re-use this article for personal use and teaching without any further permission.

Become a Fellow of BMJ Case Reports today and you can:

- Submit as many cases as you like

- Enjoy fast sympathetic peer review and rapid publication of accepted articles

- Access all the published articles

- Re-use any of the published material for personal use and teaching without further permission

For information on Institutional Fellowships contact consortiasales@bmjgroup.com

Visit casereports.bmj.com for more articles like this and to become a Fellow 